\title{
Pengembangan Kawasan Minapolitan (Studi Kasus : Pelabuhan Perikanan Samudera Cilacap)
}

\author{
Yuliarti Dian Pancawati ${ }^{1}$ \\ Diterima : Juli 2015 \\ Disetujui : 7 September 2015
}

\begin{abstract}
Cilacap district has the fishery potential of 72,000 tonnes per year, but only about $21 \%$ utilization. Ocean Fishing Port Cilacap Determination by the Ministry of Maritime Affairs and Fisheries as one of the pilot minapolitan-based fisheries led to the development of strategic Minapolitan to be implemented and is expected to provide a multiplier effect in the development of the region in Cilacap and improve the wellbeing of communities around the minapolitan region. This research was conducted with the aim to formulate the direction of development Minapolitan Ocean Fishing Port Cilacap. The technique of collecting data using interviews, documentation and observation. The sampling technique used is purposive sampling and snowball sampling. The analysis method used in this research is descriptive method qualitative and SWOT analysis. Based on the analysis and calculation of the external and internal factors Minapolitan Ocean Fishing Port Cilacap, the value of internal strengths and weaknesses by 2.2 by 0.9 , so that the difference of the rersebut factor is 1.3. External factors obtained by the probability of 2.4 and 1.0 so that the difference between the value of the threat of these two factors is equal to 1.4. Ocean Fishery Port Minapolitan Cilacap have external internal position at the point $(1,3 ; 1,4)$, namely in quadrant I. SWOT analysis of the development Minapolitan Ocean Fishing Port Cilacap generating leads recommendation subsystem upstream, downstream subsystem, and subsystem support.
\end{abstract}

Key words: development, minapolitan, SWOT Analysis

\begin{abstract}
ABSTRAK
Kabupaten Cilacap memiliki potensi perikanan tangkap sebesar 72.000 ton per tahun, namun pemanfaatannya baru sekitar 21\%. Penetapan Pelabuhan Perikanan Samudera Cilacap oleh Kementerian Kelautan dan Perikanan sebagai salah satu percontohan minapolitan berbasis perikanan tangkap menyebabkan pengembangan kawasan minapolitan strategis untuk diterapkan dan diharapkan dapat memberikan multiplier effect dalam pengembangan wilayah di Kabupaten Cilacap dan meningkatkan kesejahteraan masyarakat di sekitar kawasan minapolitan tersebut. Penelitian ini dilakukan dengan tujuan untuk merumuskan arahan pengembangan kawasan minapolitan Pelabuhan Perikanan Samudera Cilacap. Teknik pengumpulan data dilakukan dengan menggunakan wawancara, dokumentasi dan observasi. Teknik sampling yang digunakan yaitu purposive sampling dan snowball sampling. Metode analisis yang digunakan dalam penelitian ini adalah metode deskriptif kualitatif dan analisis SWOT. Berdasarkan hasil analisa dan perhitungan pada faktor eksternal dan internal kawasan minapolitan Pelabuhan Perikanan Samudera Cilacap, diperoleh nilai kekuatan internal sebesar 2,2 dan kelemahan internal sebesar 0,9, sehingga selisih kedua faktor rersebut adalah 1,3. Untuk faktor eksternal diperoleh nilai peluang sebesar 2,4 dan nilai ancaman 1,0 sehingga selisih kedua faktor tersebut yaitu sebesar 1,4. kawasan minapolitan Pelabuhan Perikanan Samudera Cilacap memiliki posisi internal eksternal pada titik $(1,3 ; 1,4)$, yaitu pada kuadran I. Analisis SWOT pengembangan kawasan minapolitan Pelabuhan Perikanan Samudera Cilacap menghasilkan arahan rekomendasi subsistem hulu, subsistem hilir, dan subsistem penunjang.
\end{abstract}

Kata kunci: pengembangan, minapolitan, perikanan.

\footnotetext{
${ }^{1}$ Direktorat Jenderal Sumber Daya Air, Kementerian Pekerjaan Umum , DI Yogyakarta

E-mail : yuliartidian@gmail.com
} 


\section{PENDAHULUAN}

Kabupaten Cilacap telah ditetapkan menjadi salah satu kawasan minapolitan dari 197 kabupaten/kota di seluruh Indonesia. Kabupaten Cilacap memiliki potensi perikanan tangkap sebesar 72.000 ton per tahun, namun pemanfaatannya baru sekitar $21 \%$. Potensi pemanfaatan kegiatan perikanan tangkap di Kabupaten Cilacap belum berkembang secara optimal, di antaranya yaitu kualitas sumber daya manusia dan sarana penangkapan ikan masih belum memadai.

Keberadaan kawasan minapolitan Pelabuhan Perikanan Samudera Cilacap diharapkan mampu memicu keberlangsungan kegiatan kawasan, baik dalam lingkup kawasan tersebut maupun sekitarnya. Pentingnya penelitian ini dilakukan mengingat Pelabuhan Perikanan Samudera Cilacap ditetapkan oleh Kementerian Kelautan dan Perikanan sebagai salah satu percontohan minapolitan berbasis perikanan tangkap sehingga pengembangan kawasan minapolitan strategis untuk diterapkan. Dengan demikian diperlukan adanya arahan pengembangan kawasan minapolitan Pelabuhan Perikanan Samudera Cilacap yang nantinya dapat dijadikan sebagai masukan/arahan dalam pengembangan kawasan tersebut.

Dari permasalahan yang telah disajikan di atas, maka penulis mengajukan pertanyaan penelitian "Bagaimanakah pengembangan kawasan minapolitan Pelabuhan Perikanan Samudera Cilacap?"

\section{METODE PENELITIAN}

Penelitian tentang pengembangan kawasan minapolitan Pelabuhan Perikanan Samudera Cilacap menggunakan beberapa metode, yaitu:

1. Metode Pengumpulan Data

Pengumpulan data dilakukan dengan wawancara mendalam, dokumentasi, dan observasi lapangan.

2. Metode Analisis Data

Metode analisis data yang digunakan dalam penelitian ini adalah :

a. Analisis deskriptif

Analisa deskriptif digunakan untuk mengidentifikasi karakteristik subsistem hulu, subsistem hilir, dan subsistem penunjang kawasan minapolitan Pelabuhan Perikanan Samudera Cilacap.

b. Analisis SWOT

Analisis SWOT menggunakan bagan dan matriks SWOT, digunakan untuk mengetahui potensi dan permasalahan yang dihadapi dalam pengembangan kawasan minapolitan Pelabuhan Perikanan Samudera Cilacap.

\section{KAJIAN TEORI}

Pengembangan wilayah merupakan upaya membangun dan mengembangkan suatu wilayah berdasarkan pendekatan spasial dengan mempertimbangkan aspek sosial budaya, ekonomi, lingkungan fisik dan kelembagaan dalam suatu kerangka perencanaan dan pengelolaan pembangunan yang terpadu (Alkadri, 2001). Menurut Peraturan Menteri Kelautan dan Perikanan Republik Indonesia Nomor Per.12/Men/2010 tentang Minapolitan, pengertian minapolitan adalah konsepsi pembangunan ekonomi 
kelautan dan perikanan berbasis kawasan berdasarkan prinsip-prinsip terintegrasi, efisiensi, berkualitas, dan percepatan.

Program pengembangan kawasan minapolitan adalah pembangunan ekonomi berbasis perikanan di kawasan agribisnis, yang dirancang dan dilaksanakan dengan jalan mensinergikan berbagai potensi yang ada untuk mendorong berkembangnya sistem dan usaha agribisnis yang berdaya saing, berbasis kerakyatan, berkelanjutan dan terdesentralisasi, yang digerakkan oleh masyarakat dan difasilitasi oleh pemerintah (Sunoto, 2010).

\section{GAMBARAN UMUM KAWASAN MINAPOLITAN PELABUHAN PERIKANAN SAMUDERA CILACAP}

Wilayah perencanaan dalam studi ini yaitu Pelabuhan Perikanan Samudera Cilacap yang termasuk dalam wilayah administrasi Kelurahan Tegalkamulyan, Kecamatan Cilacap Selatan, Kabupaten Cilacap. Adapun ruang lingkup substansial penelitian ini dibatasi pada minapolitan berbasis perikanan tangkap.

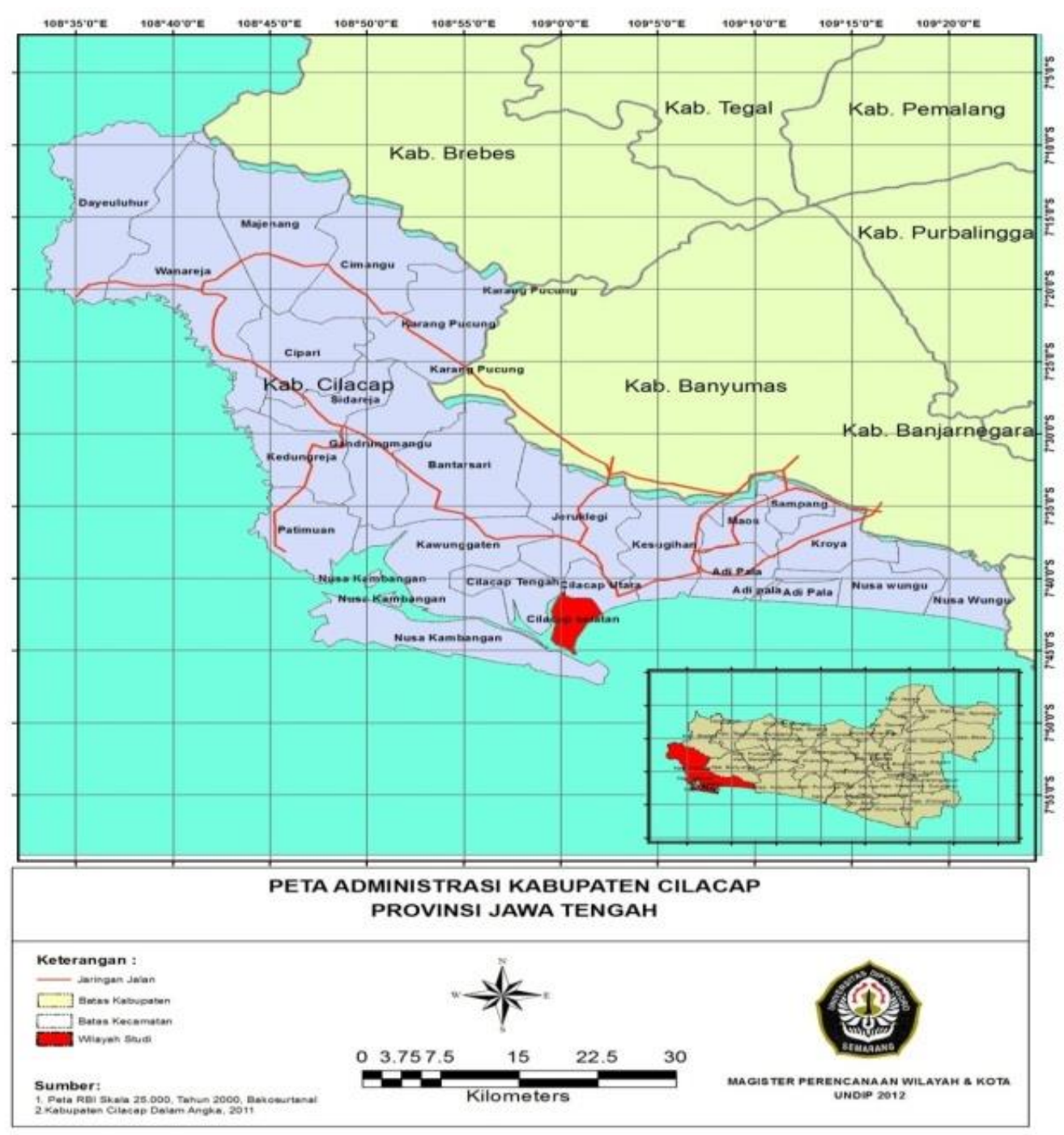

Sumber: RTRW Kabupaten Cilacap Tahun 2010

GAMBAR 1. PETA WILAYAH STUDI 


\section{HASIL DAN PEMBAHASAN}

\section{Analisis Karakteristik Subsistem Hulu Kawasan Minapolitan Pelabuhan Perikanan Samudera Cilacap}

Dalam rantai produksi hulu terdiri dari:

\section{a. Komoditas}

Komoditas unggulan di kawasan minapolitan Pelabuhan Perikanan Samudera Cilacap adalah Tuna, Cakalang, dan Udang. Hal ini sesuai dengan tujuan penetapan kawasan minapolitan Pelabuhan Perikanan Samudera Cilacap yaitu sebagai pusat tuna, cakalang, dan udang di selatan Pulau Jawa. Adapun produksi perikanan tangkap dipengaruhi iklim dan cuaca.

\section{b. Armada Penangkapan}

Armada penangkapan di kawasan minapolitan Pelabuhan Perikanan Samudera Cilacap didominasi oleh kapal tradisional. Armada perikanan tangkap ini terdiri dari :

- Kapal jukung fiberglass, terdiri dari 3-6 orang dan berangkat dengan sistem harian, berangkat pagi pulang sore.

- Perahu compreng / kapal duduk, maksimal 8 orang dan 3-5 hari melaut.

- Kapal long line, lebih dari 8 orang dan dapat berbulan-bulan di laut mencari ikan.

c. Keberadaan Sarana Tambat, Air Bersih, dan Tempat Pelelangan Ikan (TPI)

Sarana tambat yang terdapat pada Pelabuhan Perikanan Samudera Cilacap berupa kolam labuh dan dermaga. PPS Cilacap memiliki 3 kolam labuh dan 11 dermaga. Kondisinya baik dan memadai, namun perlu diwaspadai terjadinya pendangkalan kolam labuh akibat sampah rumah tangga dan sedimentasi lumpur dari Sungai Kaliyasa. Pemenuhan kebutuhan air bersih di kawasan minapolitan Pelabuhan Perikanan Samudera Cilacap yaitu menggunakan air sumur (gali maupun pompa) dan PDAM untuk keperluan sanitasi, logistik kapal, pengolahan, dan rumah tangga perkantoran. Fasilitas air bersih di Pelabuhan Perikanan Samudera Cilacap yaitu tersedia tangki air dan instalasi seluas 89 m3. Di dalam kompleks Pelabuhan Perikanan Samudera Cilacap juga terdapat Tempat Pelelangan Ikan (TPI). Kondisinya cukup baik, luas, dan bersih. Pengelolaan TPI dilakukan oleh KUD Mino Saroyo. Pelaksanaan lelang di TPI belum sesuai dengan yang diharapkan. Perlu diwaspadai pihak / bakul yang mempermainkan harga dalam proses lelang.

\section{d. Sistem Bongkar Muat}

Kegiatan bongkar muat hasil tangkapan pada Pelabuhan Perikanan Samudera Cilacap dilakukan sebagai berikut.

1. Nelayan melapor pada petugas TPI dan enumerator.

2. Petugas TPI dan enumerator mencatat volume dan jenis ikan.

3. Ikan dibawa ke TPI untuk ditimbang dan dilelang.

4. Selanjutnya kapal dapat bersandar ke dermaga istirahat, dermaga muat, atau ke dok.

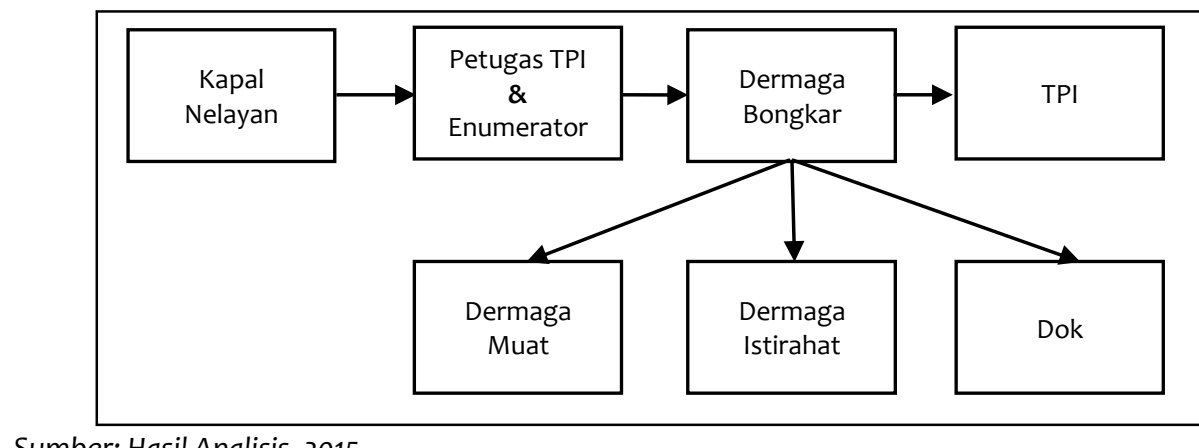

Sumber: Hasil Analisis, 2015

GAMBAR 2. SISTEM BONGKAR MUAT 


\section{e. Keterlibatan Nelayan dan Pekerja}

Dalam kegiatan perikanan tangkap, tenaga kerja di kawasan minapolitan Pelabuhan Perikanan Samudera Cilacap terdiri dari tenaga kerja ruas darat dan tenaga kerja ruas laut.

TABEL 1. TENAGA KERJA PELABUHAN PERIKANAN SAMUDERA CILACAP

\begin{tabular}{|l|r|r|r|}
\hline Tenaga Kerja & \multicolumn{1}{|c|}{ Tahun 2011 } & \multicolumn{1}{c|}{ Tahun $\mathbf{2 0 1 2}$} & \multicolumn{1}{c|}{ Tahun 2013 } \\
\hline Nelayan & $\mathbf{2 2 . 8 3 7}$ & $\mathbf{2 4 . 8 1 6}$ & $\mathbf{2 3 . 8 2 7}$ \\
\hline - Pancing / long line & 2.427 & 807 & 370 \\
\hline - Jaring Insang / gill net & 11.710 & 13.588 & 16.483 \\
\hline - Jaring lingkar & 8.694 & 8.788 & 6.871 \\
\hline - Bubu dan lainnya & 6 & 1.633 & 102 \\
\hline Non-nelayan & $\mathbf{1 . 1 4 0}$ & $\mathbf{1 . 6 1 0}$ & $\mathbf{1 . 6 2 6}$ \\
\hline - Buruh & 88 & 88 & 88 \\
\hline - Perusahaan dan KUD & 851 & 1.259 & 1.275 \\
\hline - Perseorangan & 201 & 263 & 263 \\
\hline
\end{tabular}

Sumber: Laporan Tahunan Pelabuhan Perikanan Samudera Cilacap, 2013

Penurunan tenaga kerja nelayan antara lain disebabkan oleh aktivitas penangkapan kapal <10 GT menurun dibanding tahun sebelumnya, sebagai akibat dari puncak musim penangkapan yang berlangsung sangat singkat. Adapun peningkatan tenaga kerja non-nelayan antara lain disebabkan oleh meningkatnya tenaga kerja di industri pengolahan dan galangan kapal. Sedangkan Nelayan terdiri dari:

- Nelayan kecil atau tradisional

Mereka adalah nelayan pemilik kapal yang membawa sendiri kapalnya, sekaligus berlaku sebagai nahkoda. Nelayan kecil/tradisional tidak memiliki kewajiban untuk menyetorkan hasil tangkapannya ke KUD.

- Nelayan besar atau modern

Mereka adalah nelayan pemilik kapal yang sudah menggunakan armada dan alat penangkapan ikan yang lebih modern. Nelayan ini sudah memiliki nahkoda dan awak kapal sendiri. Nelayan besar/modern memiliki kewajiban untuk menyetorkan hasil tangkapannya ke KUD untuk dijual melalui proses lelang.

\section{f. Sistem dan Distribusi Pemasaran}

Adapun mekanisme pemasaran hasil tangkap ikan di TPI Pelabuhan Perikanan Samudera Cilacap dapat digambarkan sebagai berikut.

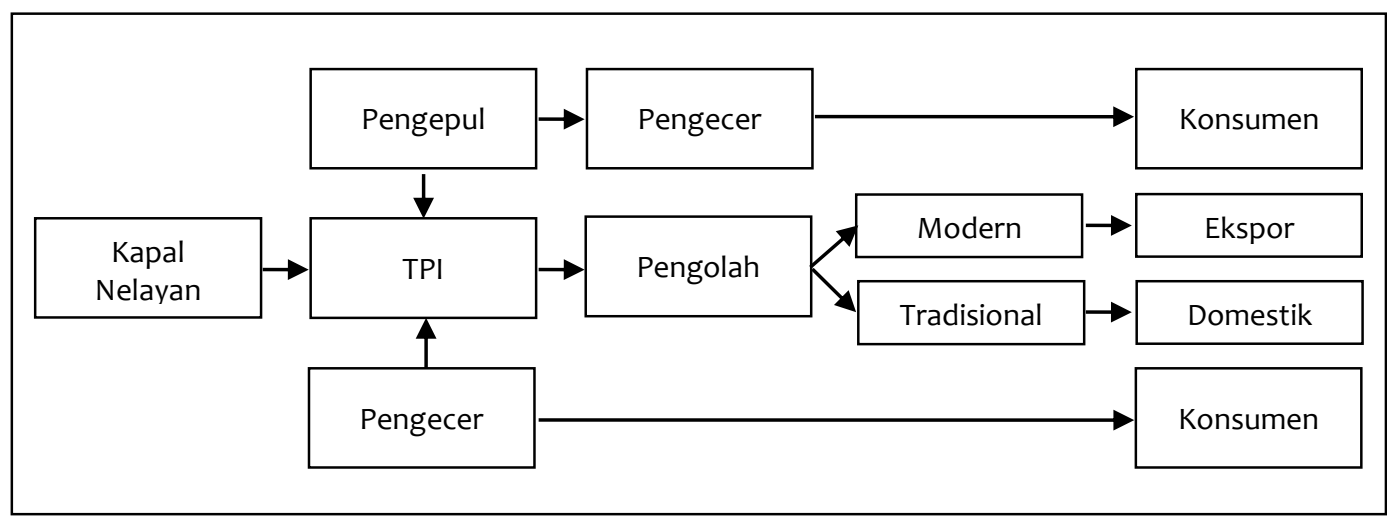

Sumber : Roadmap Minapolitan, 2010 
Ikan hasil tangkapan nelayan disetor ke TPI. Dari TPI kemudian dilelang atau dibeli oleh para pengepul maupun pengecer hingga sampai ke konsumen. Ada pula hasil tangkapan yang kemudian oleh pengolah modern ditujukan untuk keperluan ekspor, sedangkan oleh pengolah tradisional ditujukan untuk memenuhi kebutuhan domestik.

\section{g. Sentra-sentra Produksi}

Sentra produksi merupakan kumpulan unit produksi dengan keanekaragaman kegiatan di suatu lokasi tertentu. Hingga saat ini di Pelabuhan Perikanan Samudera Cilacap sudah terdapat sentra produksi, pengolahan, dan/atau pemasaran. Pelabuhan Perikanan Samudera Cilacap juga masih memiliki lahan kosong yang dapat disewa oleh investor swasta dan digunakan untuk kepentingan industri perikanan.

\section{Analisis Karakteristik Subsistem Hilir Kawasan Minapolitan Pelabuhan Perikanan Samudera Cilacap}

Dalam rantai produksi hilir terdiri dari:

\section{a. Unit-unit pengolahan}

Kawasan minapolitan Pelabuhan Perikanan Samudera Cilacap memiliki unit pengolahan ikan (UPI) baik tradisional maupun modern. Selain itu, Pelabuhan Perikanan Samudera Cilacap juga memiliki Unit Bisnis Perikanan Terpadu (UBPT) yang berperan dalam diversifikasi produk olahan.

b. Sistem dan sarana distribusi/pemasaran produk di dalam/luar kawasan

Sistem distribusi maupun pemasaran produk hasil olahan perikanan dilakukan melalui beberapa sarana antara lain:

- Pasar

Pasar merupakan salah satu sarana pemasaran yang paling efektif. Barang hasil produksi olahan beberapa unit pengolahan dipasarkan atau dijual langsung di pasar tradisional.

- Kios/toko oleh-oleh

Selain pasar, aneka produk olahan ikan juga dipasarkan di kios-kios sepanjang Pantai Teluk Penyu maupun toko oleh-oleh khas Cilacap.

- Pemasaran ke luar wilayah

Untuk pemasaran ke luar wilayah, biasanya tiap unit pengolahan telah memiliki tujuan pemasaran masing-masing yang merupakan pelanggan tetap maupun berdasarkan pesanan.

\section{Analisis Karakteristik Subsistem Hulu Kawasan Minapolitan Pelabuhan Perikanan Samudera Cilacap}

\section{a. Kelembagaan}

Kelembagaan khususnya dalam bidang perikanan yang ada di terdiri dari:

- Lembaga pemerintah

Lembaga pemerintah daerah yang terkait langsung dengan kegiatan perikanan tangkap adalah Dinas Kelautan, Perikanan, dan Pengelola Sumber Daya Kawasan Segara Anakan (DKP2SKSA) Kabupaten Cilacap dan Pelabuhan Perikanan Samudera Cilacap. Fungsi lembaga pemerintah ini adalah untuk menghubungkan antara pihak pemerintah dan pihak nelayan sebagai Pembina dalam penyuluhan dan pelatihan sumber daya manusia bagi Kelompok Usaha Bersama Nelayan. 
- HNSI cabang Cilacap

Himpunan Nelayan Seluruh Indonesia (HNSI) merupakan organisasi profesi yang menghimpun para nelayan. Keberadaan HNSI juga berperan dalam membantu mengatasi masalah yang dihadapi para nelayan, salah satunya yaitu ketika terjadi konflik atau persengketaan.

- KUD Mino Saroyo

Status KUD Mino Saroyo adalah KUD Tingkat Primer beranggotakan Nelayan yang berkedudukan di Kelurahan Cilacap, Kecamatan Cilacap Selatan, Kabupaten Cilacap, Propinsi Jawa Tengah. KUD Mino Saroyo membawahi delapan kelompok nelayan/TPI. KUD Mino Saroyo juga mempunyai beberapa unit usaha, baik simpan pinjam, permodalan, maupun unit usaha yang menyediakan peralatan perikanan maupun kebutuhan sehari-hari bagi nelayan.

- KUB

Kelompok Usaha Bersama Nelayan merupakan wadah bagi para nelayan untuk memperoleh informasi perikanan baik antarsesama KUB maupun dari pemerintah daerah. Kelompok ini dibentuk dengan tujuan untuk mempermudah dalam mengatasi permasalahan terkait kegiatan perikanan tangkap. KUB merupakan kelompok nelayan yang terdiri dari 10 orang.

Terdapat kelembagaan pemerintah dan swasta/masyarakat nelayan dengan kerja sama yang cukup baik sesuai peran masing-masing. Namun demikian, koordinasi antarlembaga pemerintah selaku pengelola/kelompok kerja minapolitan dinilai kurang. Hal yang perlu diatasi yaitu terjadinya sengketa dengan nelayan daerah lain.

\section{b. Permodalan}

Lembaga permodalan merupakan lembaga yang memberikan fasilitas bantuan permodalan untuk pengembangan usaha perikanan tangkap maupun unit usaha pengolahan perikanan. Lembaga permodalan tersebut antara lain USP Swamitra Mina, BPR/BKK Cilacap Selatan, dan pegadaian, selain itu juga terdapat bantuan permodalan dari pemerintah melalui Kelompok Usaha Bersama (KUB). Akses permodalan/fasilitas peminjaman terbatas untuk nelayan yang memiliki agunan.

c. Pendidikan dan Penyuluhan Perikanan

Pelabuhan Perikanan Samudera Cilacap menyediakan fasilitas gedung Pos Pelayanan Penyuluhan Perikanan dan tenaga penyuluh perikanan sejumlah 3 orang. Kegiatan pendidikan dan penyuluhan perikanan telah sering dilakukan, dengan difasilitasi oleh Pelabuhan Perikanan Samudera Cilacap maupun DKP2SKSA Kabupaten Cilacap bekerjasama dengan HNSI Cabang Cilacap. Inisiatif pun dapat datang dari nelayan, apabila dirasa membutuhkan. Harapannya, dengan adanya sosialisasi maupun penyuluhan perikanan dapat memberikan tambahan pengetahuan dan sarana belajar bagi masyarakat nelayan.

\section{d. Transportasi dan Infrastruktur}

\section{- Jaringan jalan}

Untuk mendukung sistem distribusi perikanan, Pelabuhan Perikanan Samudera Cilacap dilengkapi dengan akses jalan utama yang menghubungkan pelabuhan perikanan tersebut ke beberapa lokasi strategis di wilayahnya, dengan kondisi bagus dan rusak ringan. Jaringan jalan di Pelabuhan Perikanan Samudera Cilacap memiliki kapasitas 12 ton (Profil Pelabuhan Perikanan Samudera Cilacap, 2012). Jaringan jalan di kawasan minapolitan Pelabuhan Perikanan Samudera Cilacap dalam kondisi bagus dan rusak ringan. 
- Listrik

Sumber penerangan utama yang digunakan oleh penduduk di Kelurahan Tegalkamulyan serta pemenuhan listrik pada kawasan Pelabuhan Perikanan Samudera Cilacap berasal dari PLN. Pelayanan PLN pada wilayah perencanaan saat ini telah mencapai 100\% yaitu kepala keluarga (KK) telah menggunakan pelayanan PLN sebagai sumber penerangannya.

TABEL 2. BANYAKNYA RUMAH TANGGA PEMAKAI LISTRIK KELURAHAN TEGALKAMULYAN

\begin{tabular}{|l|l|c|c|}
\hline \multicolumn{2}{|c|}{ Jenis Data } & Jumlah & Persentase \\
\hline $\begin{array}{l}\text { Rumah Tangga } \\
\text { Pemakai Listrik }\end{array}$ & Rumah Tangga Pemakai Listrik PLN & $3.895 \mathrm{kk}$ & $100 \%$ \\
\cline { 2 - 4 } & Rumah Tangga Pemakai Listrik Non PLN & - & - \\
\hline
\end{tabular}

Sumber: Laporan Monografi Kelurahan Tegalkamulyan, 2012

Pemenuhan kebutuhan listrik pada kawasan Pelabuhan Perikanan Samudera Cilacap berasal dari PLN, dengan kapasitas sebesar 86 KVA (Profil Pelabuhan Perikanan Samudera Cilacap, 2012). Selain bersumber dari PLN, jaringan listrik di kawasan minapolitan Pelabuhan Perikanan Samudera Cilacap juga menggunakan genset sebagai cadangan. Jaringan listrik sebagai sarana prasarana pendukung program minapolitan dapat dikatakan cukup baik dan terpenuhi. Listrik juga menjangkau ke masing-masing TPI.

\section{Analisis SWOT Pengembangan Kawasan Minapolitan Pelabuhan Perikanan Samudera Cilacap}

Analisis SWOT ini menggunakan dan/atau mempertimbangkan faktor eksternal dan internal yang dimiliki oleh Pelabuhan Perikanan Samudera Cilacap untuk kemudian ditentukan strategi yang dapat diambil dalam rangka pengembangan kawasan minapolitan. Analisa faktor eksternal merupakan penganalisaan lingkungan eksternal kawasan minapolitan Pelabuhan Perikanan Samudera Cilacap yang berguna untuk mengetahui berbagai kemungkinan peluang dan ancaman terhadap kawasan minapolitan tersebut. Berikut adalah analisis faktor eksternal pengembangan kawasan minapolitan Pelabuhan Perikanan Samudera Cilacap.

TABEL 3. MATRIK EFAS

\begin{tabular}{|c|c|c|c|c|}
\hline No. & EFAS & B & $\mathbf{R}$ & B $\times \mathbf{R}$ \\
\hline \multirow[t]{6}{*}{1} & Peluang (Opportunities) & & & \\
\hline & Potensi perikanan lepas pantai & 0.15 & 4 & 0.6 \\
\hline & Peluang investasi & 0.15 & 4 & 0.6 \\
\hline & Diversifikasi produk olahan & 0.15 & 4 & 0.6 \\
\hline & Pemasaran hingga ke luar daerah / negeri & 0.15 & 4 & 0.6 \\
\hline & Jumlah nilai peluang & & & 2.4 \\
\hline \multirow[t]{6}{*}{2} & Ancaman (Threats) & & & \\
\hline & $\begin{array}{l}\text { Sampah rumah tangga dan sedimentasi lumpur di } \\
\text { kolam labuh }\end{array}$ & 0.15 & -2 & -0.3 \\
\hline & Tengkulak / bakul yang mempermainkan harga & 0.15 & -2 & -0.3 \\
\hline & Sengketa dengan nelayan daerah lain & 0.10 & -4 & -0.4 \\
\hline & Jumlah nilai ancaman & & & -1 \\
\hline & TOTAL & 1.00 & & 1.4 \\
\hline
\end{tabular}

Sumber: Hasil Analisis, 2015 
Analisa faktor internal merupakan penganalisaan lingkungan internal yang berguna untuk mengetahui kekuatan yang dimiliki oleh kawasan minapolitan Pelabuhan Perikanan Samudera Cilacap untuk mengembangkan usahanya dan kelemahan yang dapat menghambat perkembangan tersebut. Berikut analisis faktor internal pengembangan kawasan minapolitan Pelabuhan Perikanan Samudera Cilacap.

TABEL 4. MATRIK IFAS

\begin{tabular}{|c|c|c|c|c|}
\hline No. & IFAS & B & $\mathbf{R}$ & $\mathbf{B} \times \mathbf{R}$ \\
\hline \multirow[t]{8}{*}{1} & Kekuatan (Strengths) & & & \\
\hline & Komoditas unggulan & 0.10 & 4 & 0.4 \\
\hline & $\begin{array}{l}\text { Ketersediaan sarana tambat, air bersih, dan Tempat } \\
\text { Pelelangan Ikan (TPI) }\end{array}$ & 0.10 & 4 & 0.4 \\
\hline & Ketersediaan sumber daya manusia nelayan & 0.10 & 4 & 0.4 \\
\hline & Ketersediaan unit pengolahan ikan & 0.10 & 4 & 0.4 \\
\hline & Fasilitas gedung dan tenaga penyuluh perikanan & 0.05 & 4 & 0.2 \\
\hline & Transportasi dan infrastruktur & 0.10 & 4 & 0.4 \\
\hline & Jumlah nilai kekuatan & & & 2.2 \\
\hline \multirow[t]{7}{*}{2} & Kelemahan (Weakness) & & & \\
\hline & Armada perikanan didominasi tradisional & 0.10 & -2 & -0.2 \\
\hline & Proses lelang belum berjalan sesuai yang diharapkan & 0.10 & -2 & -0.2 \\
\hline & Koordinasi antarlembaga kurang & 0.15 & -2 & -0.3 \\
\hline & Akses permodalan terbatas & 0.10 & -2 & -0.2 \\
\hline & Jumlah nilai kelemahan & & & -0.9 \\
\hline & TOTAL & 1.00 & & 1.3 \\
\hline
\end{tabular}

Sumber: Hasil Analisis, 2015

Dari hasil analisa dan perhitungan pada faktor eksternal dan internal kawasan minapolitan Pelabuhan Perikanan Samudera Cilacap, diperoleh nilai kekuatan internal sebesar 2,2 dan kelemahan internal sebesar 0,9, sehingga selisih kedua faktor rersebut adalah 1,3. Untuk faktor eksternal diperoleh nilai peluang sebesar 2,4 dan nilai ancaman 1,0 sehingga selisih kedua faktor tersebut yaitu sebesar 1,4. Berikut ini adalah bagan hasil analisis SWOT kawasan minapolitan Pelabuhan Perikanan Samudera Cilacap. Berikut adalah Bagan dan Matriks SWOT pengembangan kawasan minapolitan Pelabuhan Perikanan Samudera Cilacap. 


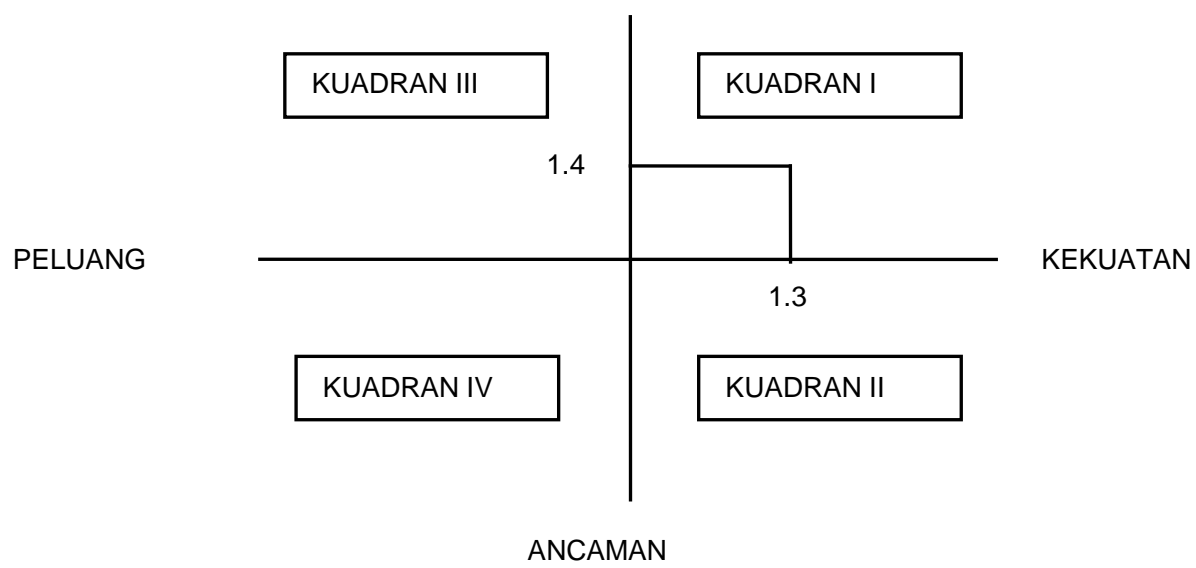

Sumber: Hasil Analisis, 2015

\section{GAMBAR 4. BAGAN SWOT PENGEMBANGAN KAWASAN MINAPOLITAN PELABUHAN PERIKANAN SAMUDERA CILACAP}

Dari bagan tersebut dapat dilihat bahwa kawasan minapolitan Pelabuhan Perikanan Samudera Cilacap memiliki posisi internal eksternal pada titik $(1,3 ; 1,4)$, yaitu pada kuadran I. Kuadran tersebut dapat diartikan bahwa strategi yang cocok untuk kawasan minapolitan yaitu strategi agresif. Dengan kata lain, kawasan minapolitan ini memiliki kekuatan dan peluang yang dapat dimanfaatkan untuk mendukung kebijakan pertumbuhan yang agresif (growth oriented strategy). Pada kawasan minapolitan ini strategi agresif akan difokuskan pada aspek pemasaran, produksi, dan teknis. Dengan fokus pada aspek tersebut, diharapkan mampu bersaing.

Selain dari bagan analisis SWOT, maka perlu juga penyusunan strategi dengan menggunakan matriks SWOT. Matriks SWOT ini juga digunakan untuk menyusun rencana strategi yang didasarkan pada faktor strengths opportunities (SO), strengths threats (ST), weakness opportunities (WO), dan weakness threats (WT). Dengan demikian diharapkan akan menghasilkan alternatif strategi yang lebih detail dan aplikatif, yang dapat digunakan untuk pengembangan kawasan minapolitan di Pelabuhan Perikanan Samudera Cilacap. 
TABEL 5. MATRIKS SWOT PENGEMBANGAN KAWASAN MINAPOLITAN PELABUHAN PERIKANAN SAMUDERA CILACAP

\begin{tabular}{|c|c|c|}
\hline EFAS & $\begin{array}{l}\text { OPPORTUNITIES (O) } \\
\text { - Potensi perikanan lepas } \\
\text { pantai } \\
\text { - Peluang investasi lahan } \\
\text { komersial } \\
\text { - Adanya diversifikasi } \\
\text { produk olahan } \\
\text { - Pemasaran hingga ke luar } \\
\text { daerah / negeri }\end{array}$ & $\begin{array}{l}\text { THREATS }(\mathrm{T}) \\
\text { - Sampah rumah tangga } \\
\text { dan sedimentasi lumpur } \\
\text { menyebabkan } \\
\text { pendangkalan kolam } \\
\text { labuh } \\
\text { - Tengkulak/bakul yang } \\
\text { mempermainkan harga } \\
\text { - Sengketa dengan nelayan } \\
\text { daerah lain }\end{array}$ \\
\hline $\begin{array}{l}\text { STRENGHTS (S) } \\
\text { - Komoditas unggulan } \\
\text { - Sarana tambat, air bersih, dan } \\
\text { TPI } \\
\text { - Ketersediaan SDM nelayan } \\
\text { - Unit pengolahan ikan modern } \\
\text { dan tradisional } \\
\text { - Fasilitas gedung dan tenaga } \\
\text { penyuluh perikanan } \\
\text { - Transportasi dan infrastruktur } \\
\text { memadai }\end{array}$ & $\begin{array}{l}\text { STRATEGI SO } \\
\text { - Mendorong investor } \\
\text { untuk menanamkan } \\
\text { modal } \\
\text { - Mendorong diversifikasi } \\
\text { produk olahan } \\
\text { - Meningkatkan sarana } \\
\text { dan kegiatan pemasaran }\end{array}$ & $\begin{array}{l}\text { STRATEGI ST } \\
\text { - Pemeliharaan kolam labuh } \\
\text { dengan pengerukan } \\
\text { secara berkala } \\
\text { - Menindaktegas pelaku } \\
\text { kecurangan }\end{array}$ \\
\hline $\begin{array}{l}\text { WEAKNESS (W) } \\
\text { - Armada perikanan didominasi } \\
\text { tradisional } \\
\text { - Pelaksanaan pelelangan ikan } \\
\text { belum sesuai dengan yang } \\
\text { diharapkan } \\
\text { - Koordinasi antarlembaga } \\
\text { pemerintah kurang } \\
\text { - Permodalan terbatas }\end{array}$ & $\begin{array}{l}\text { STRATEGI WO } \\
\text { - Mendorong peningkatan } \\
\text { armada modern } \\
\text { - Meningkatkan efektifitas } \\
\text { bantuan permodalan }\end{array}$ & $\begin{array}{l}\text { STRATEGI WT } \\
\text { - Mendorong KUD Mino } \\
\text { Saroyo untuk } \\
\text { melaksanakan pelelangan } \\
\text { ikan setiap hari secara } \\
\text { murni } \\
\text { - Meningkatkan koordinasi } \\
\text { antarlembaga dan } \\
\text { antardaerah }\end{array}$ \\
\hline
\end{tabular}

Sumber: Hasil Analisis, 2015

\section{KESIMPULAN DAN REKOMENDASI}

\section{Kesimpulan}

Pelabuhan Perikanan Samudera Cilacap sebagai zona inti minapolitan berbasis perikanan tangkap diharapkan berdampak positif untuk pengembangan ekonomi di Kabupaten Cilacap sehingga dapat meningkatkan kesejahteraan masyarakat. Pengembangan kawasan minapolitan Pelabuhan Perikanan Samudera Cilacap belum optimal karena baru terbatas pada penyediaan sarana dan prasarana minapolitan, belum keterkaitan menyeluruh antara subsistem hulu, subsistem hilir, dan subsistem penunjang kawasan minapolitan.

Kendala dalam pelaksanaan minapolitan yaitu koordinasi antara pihak-pihak yang terkait dalam pengelolaan pengembangan kawasan minapolitan perikanan tangkap di Kabupaten Cilacap, baik dari pemerintah dalam hal ini yaitu Dinas Kelautan, Perikanan dan Pengelola Sumber Daya Kawasan Segara Anakan (DKP2SKSA) Kabupaten Cilacap dan Pelabuhan Perikanan Samudera Cilacap selaku Tim Pokja Minapolitan. Dengan 
demikian, dibutuhkan arahan pengembangan kawasan minapolitan yaitu pengembangan kegiatan perikanan dari hulu hingga ke hilir dengan memanfaatkan potensi dan sarana prasarana/fasilitas yang dimiliki.

\section{REKOMENDASI}

Arahan dalam pengembangan kawasan minapolitan Pelabuhan Perikanan Samudera Cilacap adalah sebagai berikut.

1. Arahan rekomendasi subsistem hulu.

- Mendorong peningkatan armada modern.

- Pengerukan kolam labuh secara berkala.

- Mendorong KUD untuk melaksanakan proses lelang setiap hari secara murni.

- Melakukan pengawasan terhadap pelaksanaan lelang dan menindaktegas pelaku kecurangan.

- Mendorong investor untuk menanamkan modal.

2. Arahan rekomendasi subsistem hilir.

- Mendorong diversifikasi produk olahan.

- Meningkatkan sarana dan kegiatan pemasaran.

3. Arahan rekomendasi subsistem penunjang.

- Meningkatkan koordinasi antarlembaga dan antardaerah.

- Meningkatkan efektifitas bantuan permodalan.

\section{DAFTAR PUSTAKA}

Alkadri. 2001. Manajemen Teknologi untuk Pengembangan Wilayah : Konsep Dasar, Contoh Kasus, dan Implikasi Kebijakan. Jakarta : Pusat Pengkajian Kebijakan Teknologi Pengembangan Wilayah (P2KTPW) BPPT (Badan Pengkajian dan Penerapan Teknologi).

Laporan Tahunan 2013. Pelabuhan Perikanan Samudera Cilacap.

Profil Pelabuhan Perikanan Samudera Cilacap 2012.

Peraturan Menteri Kelautan dan Perikanan Republik Indonesia Nomor: PER.12/MEN/2010 tentang Minapolitan.

Rangkuti, Freddy. 2002. Analisa SWOT : Teknik Membedah Kasus Bisnis. Jakarta : Gramedia Pustaka Utama.

Roadmap Minapolitan Perikanan Tangkap dan Budidaya Kabupaten Cilacap Tahun 20112014.

Sunoto. 2010. Arah Kebijakan Pengembangan Konsep Minapolitan di Indonesia. Bulletin Penataan Ruang Edisi Maret-April 2010. 